\title{
Antibacterial Potential of Star Anise (Illicium verum Hook. f.) Against Food Pathogen Bacteria
}

\author{
EVELINE* AND AGUSTIN NOVITA
}

\author{
Food Technology Department, Faculty of Science and Technology, University of Pelita Harapan, \\ MH. Thamrin Boulevard 1100 Lippo Village, Kelapa Dua, Karawaci, Tangerang, Indonesia.
}

\begin{abstract}
Star anise (Illicium verum Hook. f.) is commonly used as spice and flavor enhancer in food. Previous research revealed the presence of active compound which could inhibit bacterial growth. Thus, in order to apply star anise as natural antibacterial agent in food product, a further research concerning antibacterial activity and stability of star anise was conducted. Crude extract of star anise was obtained using ethanol and acetone with maceration method for 3 days, then diluted to 10, 20,30,40, and 50\% (w/v). Well diffusion was conducted against three food spoilage bacteria (Staphylococcus aureus, Escherichia coli, and Bacillus cereus). Extract from ethanol with $30 \%$ concentration was selected as the best extract in which inhibit more than $6 \mathrm{~mm}$ inhibition zone with MIC and MBC value: $1.59 \%$ and $6.36 \%$ (S. aureus), $1.04 \%$ and $4.18 \%$ (E. coli), and $0.59 \%$ and $2.39 \%($ B. cereus). This selected extract was used to test the extract stability against 4 levels of heating temperature $\left(60,70,80\right.$, and $\left.90^{\circ} \mathrm{C}\right)$ for 2 levels of heating time ( 15 and 30 minutes), and 4 levels of $\mathrm{pH}(4,5,6$, and 7 ). Based on our results, different heating treatment and $\mathrm{pH}$ caused extract instability. Star anise extract was more stable at $60^{\circ} \mathrm{C}$ for 15 minutes heating treatment and $\mathrm{pH} 4$, which resulting the lowest inhibition zone reduction compared to control extract. Star anise extract was categorized as low toxic compound $\left(\mathrm{LC}_{50}=212.09 \mathrm{ppm}\right)$. Terpenoids (anethole, 2,6-dimethyl-6-(4methyl-3-pentenyl)-2-norpinene, $\beta$-caryophyllene, $\beta$-bisabolene) was founded as major antibacterial compound in star anise extract; fatty acid (6-octadecenoic acid, hexadecanoic acid, stearic acid) and benzaldehyde (4anisaldehyde, p-allylanisole) were also founded as minor compound.
\end{abstract}

Key words: antibacterial, Illicium verum Hook. f., $\mathrm{pH}$, stability, temperature, time

Bunga lawang (Illicium verum Hook. f.) umumnya dimanfaatkan sebagai rempah dan perisa pada makanan. Penelitian terdahulu mengungkap adanya senyawa aktif yang berpotensi menghambat pertumbuhan bakteri. Hal ini mendorong dilakukan penelitian lebih lanjut agar diketahui aktivitas dan stabilitas bunga lawang sebagai senyawa antibakteri alami yang dapat diterapkan dalam produk pangan. Ekstrak kasar bunga lawang diperoleh dari ekstraksi dengan etanol dan aseton selama 3 hari pada konsentasi 10, 20, 30, 40, dan 50\% (b/v). Pengujian difusi sumur dilakukan terhadap tiga bakteri perusak pangan (Staphylococcus aureus, Escherichia coli, dan Bacillus cereus). Ekstrak 30\% dengan pelarut etanol merupakan ekstrak terpilih penghasil zona hambat lebih dari $6 \mathrm{~mm}$ dengan MIC dan MBC berurutan sebesar 1,59\% dan 6,36\% (S. aureus), 1,04\% dan 4,18\% (E. coli), 0,59\% dan $2,39 \%$ (B. cereus). Ekstrak terpilih digunakan dalam tahap pengujian stabilitas ekstrak terhadap suhu pemananasan $\left(60,70,80\right.$, dan $\left.90^{\circ} \mathrm{C}\right)$, waku pemanasan $(15$ dan 30 menit), dan $\mathrm{pH}(4,5,6$, dan 7$)$. Perlakuan panas dan perubahan $\mathrm{pH}$ menyebabkan ketidakstabilan ekstrak. Ekstrak bunga lawang lebih stabil pada suhu $60^{\circ} \mathrm{C}$ selama 15 menit dan $\mathrm{pH}$ 4, kondisi ini menghasilkan ekstrak dengan penurunan zona hambat terkecil terhadap nilai penghambatan ekstrak kontrol. Ekstrak bunga lawang termasuk dalam kategori senyawa toksik rendah $\left(\mathrm{LC}_{50}\right.$ $=212,09 \mathrm{ppm})$ dalam fungsinya sebagai senyawa antibakteri yang mengandung senyawa antibakteri mayor berupa golongan terpenoid (anethole, 2,6-dimethyl-6-(4-methyl-3-pentenyl)-2-norpinene, $\beta$-caryophyllene, $\beta$ bisabolene); dan senyawa antibakteri minor berupa golongan asam lemak (6-octadecenoic acid, hexadecanoic acid, stearic acid) dan golongan benzaldehide (4-anisaldehyde, p-allylanisole).

Kata kunci: antibakteri, Illicium verum Hook. f., pH, stabilitas, suhu, waktu

Star anise (Illicium verum Hook. f.) is spice which commonly used as traditional medicine. This plant is commonly found at tropical and subtropical area in Asia (Ahmad and Youssef, 2015; Sivakumar et al. 2016). Star anise's essential oil consists of $89.5 \%$ transanethole, which acts as antimicrobial, antimicotoxins, antioxidants, and insecticide compound (Aly et al.

*Corresponding author: Phone: +62-8128187282; Email: eveline.fti@uph.edu
2016; Wei et al. 2014). The potency of star anise as antimicrobial agent then encouraged further research to increase the possibility to use star anise as natural antibacterial agent in food industry.

Crude extract of star anise was obtained using maceration method with ethanol (polarity index 5.2) and acetone (polarity index 5.1) as solvent for 3 days. The crude extract then diluted into 5 levels of concentration $(10,20,30,40$, and $50 \%(\mathrm{w} / \mathrm{v}))$ and tested with well diffusion method against 3 species of 
bacteria (S. aureus, E. coli, and B. cereus). Previous research regarding solvent used in antibacterial compound extraction to apply in food product by Ahmad and Youssef (2015), Dasgupta and Klein (2014), and Das and Kumar (2013) showed that ethanol and acetone work effectively to extract phytochemical compound (flavonoids, alkaloids, triterpenoids, tannins, steroids, and glycosides) which can be used as antibacterial agent against E. coli, S. aureus, and $B$. subtilis. Aguda and Chen (2016) added that both ethanol and acetone were categorized as Generally Recognized as Safe (GRAS) by Food and Drug Administration (FDA).

The selected concentration was then used to test extract stability against 4 levels of heating temperature $\left(60,70,80\right.$, and $\left.90^{\circ} \mathrm{C}\right)$ for 2 levels of heating time $(15$ and 30 minutes), and 4 levels of $\mathrm{pH}(4,5,6$, and 7$)$. The heating temperature and time were determined based on previous research by Peter (2001) regarding the stability of trans-anethole in fennel extract (Foeniculum vulgare) at $70^{\circ} \mathrm{C}$ for 15 minutes heating treatment. Research by Handayani and Sriherfyna (2016) and Surono et al. (2016) also showed that bioactive compounds were commonly degraded at temperature more than $50^{\circ} \mathrm{C}$, also the common temperature used in food processing starts around $63^{\circ} \mathrm{C}$ for 30 minutes. Level of $\mathrm{pH}$ used in this research was determined based on the $\mathrm{pH}$ of food product (3.5-7.0) and the ability of pathogenic microbes to grow at $\mathrm{pH}$ 4.0-9.5 (Surono et al. 2016). Analysis about Minimum Inhibitory Concentration (MIC), Minimum Bactericidal Concentration (MBC), toxicity analysis using Brine Shrimp Lethality Test (BSLT), and Gas Chromatography-Mass Spectrometry (GC-MS) were also conducted in this research. The results of this research hopefully can be used as source of information, especially regarding optimum conditions of star anise extract for application in food industry.

\section{MATERIALS AND METHODS}

Material. Dry star anise ("SAJP" brand), ethanol, acetone, alcohol, dimethyl sulfoxide (DMSO), hexane, $\mathrm{NaCl} 0.85 \%$, nutrient agar (NA), nutrient broth (NB), $\mathrm{HCl} 0.1 \mathrm{~N}, \mathrm{NaOH} 0.1 \mathrm{~N}, \mathrm{pH} 4$ and 7 buffer solution, and isolates of Staphylococcus aureus (Gram positive bacteria), Escherichia coli (Gram negative bacteria, and Bacillus cereus (spore bacteria).

Sample Preparation Phase Methods. Sample preparation steps that were performed to obtain star anise powder, included size reduction (35 mesh), conducting proximate analysis, and determining optimum time of tested bacteria growth using bacterial growth curve. Total colony used for well diffusion test in this research were $10^{8} \mathrm{CFU} \mathrm{mL}^{-1}$.

Phase I Methods. Phase I research (Fig 1) started with maceration process of star anise powder $(1: 10 ; 20$ $25^{\circ} \mathrm{C}$ ) using ethanol and acetone for 3 days. Extraction was executed by constant shaking at $150 \mathrm{rpm}$. Filtration of the filtrate (using Whatman No.1 and Buchner vacuum) and evaporation $\left(40{ }^{\circ} \mathrm{C}\right.$; $35 \mathrm{rpm}$; 1 hour) were carried out in order to produce antibacterial compound extract. Extract was then diluted to 5 levels of concentration $(10,20,30,40$, and $50 \%(\mathrm{w} / \mathrm{v}))$. Antimicrobial activity test was conducted using well diffusion method in order to determine selected extract which was the best extract concentration in this research.

Phase II Methods. In phase II (Fig 1), the stability test was performed by setting the extract into different temperature $\left(60,70,80\right.$, and $\left.90{ }^{\circ} \mathrm{C}\right)$ with different heating time (15 and 30 minutes), and $\mathrm{pH}(4,5,6$, and 7); MIC and MBC test; component analysis using GCMS; and toxicity test (Sangi 2012) were also performed toward selected extract from phase I research.

Analysis. Proximate analysis in phase I research was used to determine the water content of dry star anise powder (AOAC 2005). MIC and MBC in Phase II research were used to analyze the minimum value needed to inhibit bacterial growth and kill $90 \%$ of tested bacteria (Bloomfield 1991). In addition, to test the cytotoxicity of extract, we used BSLT method (Sangi 2012), whilst GC-MS test was used to analyze major antibacterial compound in extract.

Experimental Design. Experimental design used in phase I research was Completely Randomized Design with one factor and five levels $\left(10 \%\left[\mathrm{~A}_{1}\right], 20 \%\right.$ $\left.\left[\mathrm{A}_{2}\right], 30 \%\left[\mathrm{~A}_{3}\right], 40 \%,\left[\mathrm{~A}_{4}\right]\right)$, and $\left.50 \%\left[\mathrm{~A}_{5}\right]\right)$ with three repetition. Experimental design used in phase II research for stability against heating temperature and time was Completely Randomized Design with two factors and three repetition. Temperature factor used four levels which were: $60\left(\mathrm{~A}_{1}\right), 70\left(\mathrm{~A}_{2}\right), 80\left(\mathrm{~A}_{3}\right)$, and $90^{\circ} \mathrm{C}\left(\mathrm{A}_{4}\right)$; while heating time used two levels which were: 15 minutes $\left(B_{1}\right)$, and 30 minutes $\left(B_{2}\right)$. Stability test against $\mathrm{pH}$ value was performed using Completely Randomized Design with one factor and three repetition. Levels of $\mathrm{pH}$ were: $4\left(\mathrm{~A}_{1}\right), 5\left(\mathrm{~A}_{2}\right), 6\left(\mathrm{~A}_{3}\right)$, and $7\left(\mathrm{~A}_{4}\right)$. 


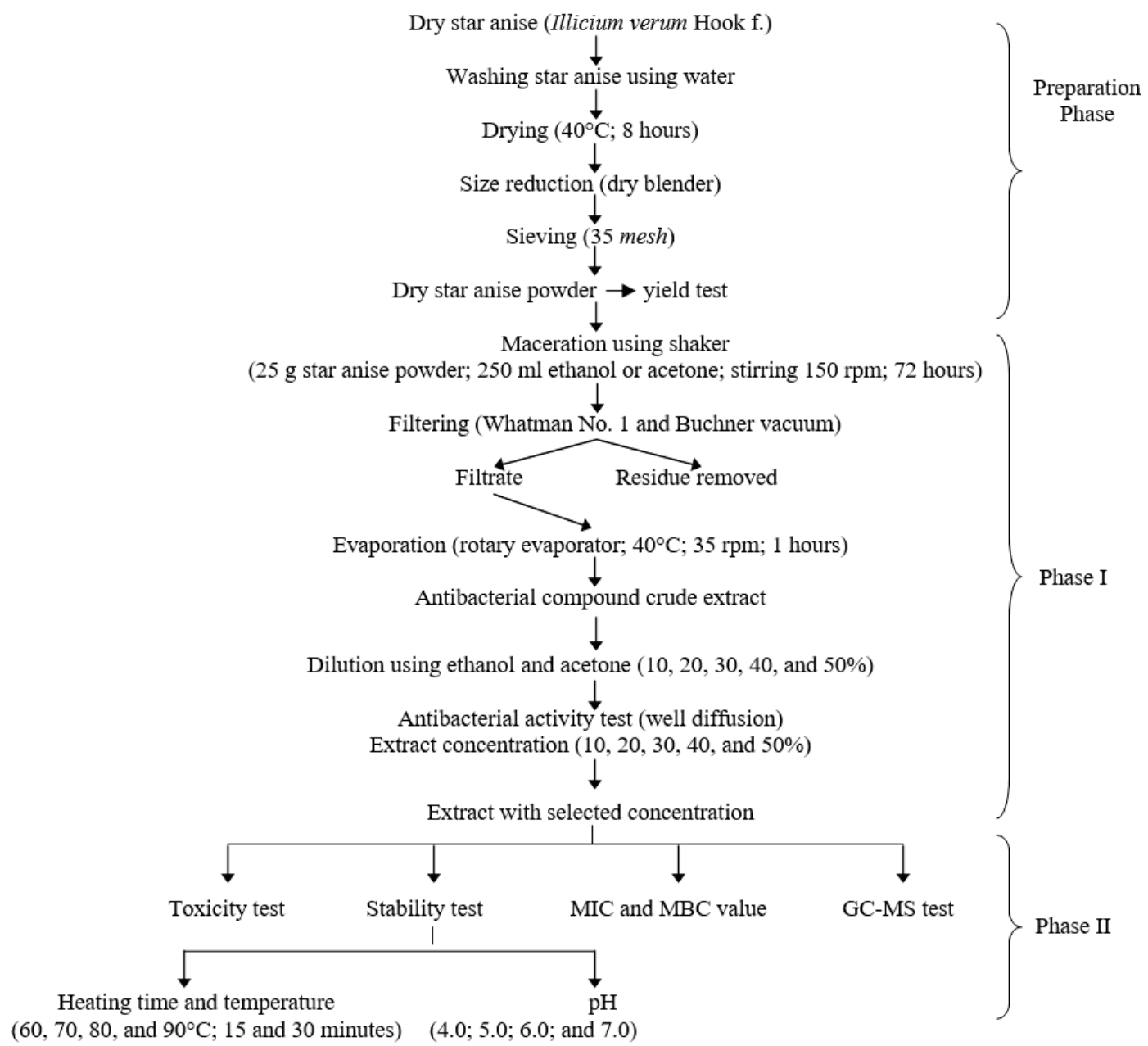

Fig 1 Flowchart of star anise antibacterial activity research.

Source: Modification from Ahmad and Youssef (2015); Badal and Degoda (2017); Nam et al. (2017); Shete and Chitanand (2014); Wei et al. (2014)

\section{RESULTS}

Phase I. The yield of 72 hours maceration extraction using ethanol was $15.19 \pm 0.35 \%$ and $12.45 \pm 0.37 \%$ using acetone. Ethanol is a polar solvent, so it is easy to attract most of the polar in star annise.

The Bacteria Used. Bacteria used in test were in $\log$ phase after 6 hours of incubation period. Total colony used for well diffusion in this research were $10^{8}$ CFU $\mathrm{mL}^{-1}$; total colony of $S$. aureus, E. coli, and $B$. cereus used in test were $1.9 \times 10^{8} \mathrm{CFU} \mathrm{mL}^{-1}, 1.8 \times 10^{8}$ $\mathrm{CFU} \mathrm{mLl}{ }^{-1}$, and $2.5 \times 10^{8} \mathrm{CFU} \mathrm{mL}^{-1}$.

Inhibition Diameter Based on Extract Concentration. Table 1 showed that extract concentration significantly affecting inhibition diameter $(\mathrm{p}<0.05)$. The bigger extract concentration would produce larger inhibition diameter. Table 1 also showed that ethanol was proven to be effective in inhibiting the growth of tested bacteria. At a concentration of $30 \%$, ethanol was able to inhibit the bacteria with more than $6 \mathrm{~mm}$ inhibition diameter, it was minimal inhibition according to Khalaphallah (2015); thus, the extract concentration used for the next phase was $30 \%$.

Phase II. Phase II Research was done in order to determine the stability against heating temperature $(60$, 70,80 , and $90{ }^{\circ} \mathrm{C}$ ) and heating time (15 and 30 minutes), and $\mathrm{pH}(4,5,6$, and 7$)$. In this phase, $\mathrm{MIC}$ and $\mathrm{MBC}$ test, toxicity test, and component analysis using GC-MS were also done towards selected extract from phase I.

Extract Stability Based on Heating Temperature and Time. Statistical test results (Table 2) showed that stability of antibacterial activity of extract on $S$. aureus and E. coli was affected by heating temperature and time $(\mathrm{p}<0.05)$, but there was no interaction between these two factors; when tested on B. cereus (Table 3 ), stability of antibacterial activity of extract was affected by both factors (heating temperature and time) interactively $(p<0.05)$. Higher 
Table 1 Phase I analysis results (inhibition diameter based on extract concentration)

\begin{tabular}{ccccc}
\hline \multirow{2}{*}{ Concentration (\%) } & \multirow{2}{*}{ Solvent } & \multicolumn{3}{c}{ Inhibition diameter $(\mathrm{mm})$} \\
\cline { 3 - 5 } & & S. aureus & E. coli & B. cereus \\
\cline { 2 - 5 } \multirow{2}{*}{10} & Ethanol & $4.25 \pm 0.15^{\mathrm{a}}$ & $4.83 \pm 0.19^{\mathrm{l}}$ & $4.89 \pm 0.16^{\mathrm{v}}$ \\
& Acetone & $4.30 \pm 0.18^{\mathrm{a}}$ & $3.43 \pm 0.16^{\mathrm{k}}$ & $3.25 \pm 0.05^{\mathrm{t}}$ \\
\hline \multirow{2}{*}{20} & Ethanol & $4.88 \pm 0.21^{\mathrm{b}}$ & $5.88 \pm 0.26^{\mathrm{mn}}$ & $4.95 \pm 0.20^{\mathrm{v}}$ \\
& Acetone & $5.19 \pm 0.21^{\mathrm{bc}}$ & $5.09 \pm 0.24^{1}$ & $4.39 \pm 0.16^{\mathrm{u}}$ \\
\hline \multirow{2}{*}{30} & Ethanol & $6.65 \pm 0.04^{\mathrm{d}}$ & $6.49 \pm 0.28^{\mathrm{o}}$ & $6.04 \pm 0.08^{\mathrm{x}}$ \\
& Acetone & $5.43 \pm 0.19^{\mathrm{c}}$ & $5.72 \pm 0.28^{\mathrm{m}}$ & $5.06 \pm 0.14^{\mathrm{vw}}$ \\
\hline \multirow{2}{*}{40} & Ethanol & $7.35 \pm 0.34^{\mathrm{e}}$ & $7.07 \pm 0.17^{\mathrm{p}}$ & $6.15 \pm 0.24^{\mathrm{x}}$ \\
& Acetone & $6.42 \pm 0.29^{\mathrm{d}}$ & $6.18 \pm 0.30^{\mathrm{no}}$ & $5.40 \pm 0.20^{\mathrm{w}}$ \\
\hline \multirow{2}{*}{50} & Ethanol & $7.91 \pm 0.31^{\mathrm{f}}$ & $8.04 \pm 0.27^{\mathrm{q}}$ & $6.89 \pm 0.33^{\mathrm{z}}$ \\
& Acetone & $7.14 \pm 0.29^{\mathrm{e}}$ & $6.49 \pm 0.20^{\mathrm{o}}$ & $6.51 \pm 0.28^{\mathrm{y}}$ \\
\hline
\end{tabular}

Different notation showed that there was significant difference $(\mathrm{p}<0.05)$; not compared between bacteria

Table 2 Phase II analysis results (extract stability based on heating temperature and time on Staphylococcus aureus and Escherichia coli)

\begin{tabular}{|c|c|c|c|c|c|c|c|c|}
\hline & \multicolumn{5}{|c|}{$\begin{array}{c}\text { Inhibition diameter }(\mathrm{mm}) \\
\text { based on heating temperature }\end{array}$} & \multicolumn{3}{|c|}{$\begin{array}{c}\text { Inhibition diameter (mm) } \\
\text { based on heating time (minutes) }\end{array}$} \\
\hline & Control & $60^{\circ} \mathrm{C}$ & $70^{\circ} \mathrm{C}$ & $80^{\circ} \mathrm{C}$ & $90^{\circ} \mathrm{C}$ & Control & 15 & 30 \\
\hline S. aureus & $6.36 \pm 0.26^{\mathrm{b}}$ & $7.03 \pm 0.28^{\mathrm{a}}$ & $5.66 \pm 0.28^{\mathrm{c}}$ & $4.61 \pm 0.17^{\mathrm{d}}$ & $3.97 \pm 0.22^{\mathrm{e}}$ & $6.36 \pm 0.26^{\mathrm{h}}$ & $5.46 \pm 0.35^{\mathrm{hi}}$ & $5.18 \pm 0.36^{\mathrm{i}}$ \\
\hline
\end{tabular}

Different notation showed that there was significant difference $(\mathrm{p}<0.05)$; not compared between bacteria and heat treatment

Table 3 Phase II analysis results (extract stability based on heating temperature and time on Bacillus cereus)

\begin{tabular}{ccc}
\hline $\begin{array}{c}\text { Heating temperature } \\
\left({ }^{\circ} \mathrm{C}\right)\end{array}$ & Heating time (minutes) & $\begin{array}{c}\text { Inhibition diameter }(\mathrm{mm}) \\
\text { B. cereus }\end{array}$ \\
\hline Control (no heat treatment) $\left(\sim 25^{\circ} \mathrm{C}, 0\right.$ minute) & & $6.68 \pm 0.12^{\mathrm{a}}$ \\
\hline \multirow{2}{*}{60} & 15 & $6.43 \pm 0.24^{\mathrm{a}}$ \\
& 30 & $6.00 \pm 0.17^{\mathrm{b}}$ \\
\hline \multirow{2}{*}{70} & 15 & $5.43 \pm 0.21^{\mathrm{c}}$ \\
& 30 & $5.29 \pm 0.19^{\mathrm{c}}$ \\
\hline \multirow{2}{*}{80} & 15 & $4.11 \pm 0.08^{\mathrm{de}}$ \\
& 30 & $4.30 \pm 0.16^{\mathrm{d}}$ \\
\hline \multirow{2}{*}{90} & 15 & $4.22 \pm 0.15^{\mathrm{de}}$ \\
& 30 & $3.95 \pm 0.14^{\mathrm{e}}$ \\
\hline
\end{tabular}

Different notation showed that there was significant difference $(\mathrm{p}<0.05)$

Table 4 Phase II analysis results (extract stability based on $\mathrm{pH}$

\begin{tabular}{cccc}
\hline $\mathrm{pH}$ & S. aureus & Inhibition diameter $(\mathrm{mm})$ & B. cereus \\
\hline Control $(\mathrm{pH} \sim 5.66)$ & $6.63 \pm 0.20^{\mathrm{a}}$ & $6.59 \pm 0.23^{\mathrm{n}}$ & $6.38 \pm 0.29^{\mathrm{a}}$ \\
4.0 & $6.24 \pm 0.14^{\mathrm{b}}$ & $6.83 \pm 0.25^{\mathrm{m}}$ & $6.54 \pm 0.27^{\mathrm{a}}$ \\
5.0 & $6.22 \pm 0.10^{\mathrm{b}}$ & $6.67 \pm 0.32^{1}$ & $6.40 \pm 0.29^{\mathrm{a}}$ \\
6.0 & $6.10 \pm 0.28^{\mathrm{b}}$ & $5.86 \pm 0.18^{\mathrm{k}}$ & $5.59 \pm 0.25^{\mathrm{b}}$ \\
7.0 & $3.42 \pm 0.16^{\mathrm{a}}$ & $2.44 \pm 0.12^{\mathrm{k}}$ & $2.13 \pm 0.10^{\mathrm{c}}$ \\
\hline
\end{tabular}

Different notation showed that there was significant difference $(\mathrm{p}<0.05)$; not compared between bacteria

heating temperature and time tend to produce smaller inhibition diameter. When heated for more than $60^{\circ} \mathrm{C}$ for 15 minutes heating period, the extract was not showing active antibacterial activity (inhibition diameter $<6 \mathrm{~mm}$ ).

Extract Stability Based on pH. Changes in $\mathrm{pH}$ affected the inhibition diameter $(\mathrm{p}<0.05)$. The addition of $\mathrm{HCl} 0.1 \mathrm{M}$ as the acid regulator and $\mathrm{NaOH} 0.1 \mathrm{M}$ as base regulator on extract gave significant difference compared to control extract with $\mathrm{pH} \sim 5.66$ (the extract without any treatment). Table 4 showed that $\mathrm{pH}$ escalation in extract towards neutral produced smaller inhibition diameter, and antibacterial compound in star anise extract was more stable at $\mathrm{pH}$ 4-5.

MIC and MBC. MIC and MBC value were determined based on selected extract's (30\% 
concentration) inhibition zone. MIC value was the minimum concentration needed to inhibit $90 \%$ growth of tested bacteria, while MBC value was the minimum concentration needed to kill $90 \%$ of tested bacteria (Zadrazilova et al. 2015). MIC and MBC test results were $1.59 \%$ and $6.36 \%$ for $S$. aureus, $1.04 \%$ and $4.18 \%$ for E. coli, and $0.59 \%$ and $2.39 \%$ for B. cereus (Table $1)$.

Toxicity. Selected star anise extract was categorized as low toxic compound $\left(\mathrm{LC}_{50}=212.09\right.$ $\mathrm{ppm}$ ) in its function as antibacterial compound that contains as follows (in the order of the best antibacterial potential).

GC-MS. Star anise extract contained major antibacterial compounds in the form of terpenoids (anethole, $\beta$-caryophyllene, $\beta$-bisabolene, 2,6dimethyl-6-(4-methyl-3-pentenyl)-2-norpinene, $\beta$ Linalool, p-allylanisole, Trans- $\gamma$-bisabolene); and minor antibacterial compounds in the form of fatty acids (6-octadecenoic acid, hexadecanoic acid, stearic acid) and benzaldehyde (methoxy acetophenone, 4anisaldehyde, 3-propenylphenol).

\section{DISCUSSION}

Star anise extract made using ethanol for 3 days extraction time at $30 \%$ concentration effectively exerted best inhibition toward three food spoiling bacteria (Staphylococcus aureus, Escherichia coli, and Bacillus cereus). According to Baldosano et al. (2015), most of the compounds in star anise tend to be polar, thus the amount extracted using ethanol solvent was greater than acetone solvent. More active compounds found in an extract would produce larger inhibition diameter (Khasanah 2014). According to Khalaphallah (2015), antimicrobial compound was categorized as active if the inhibition diameter is more than $6 \mathrm{~mm}$. Antibacterial activity test result of star anise extract using ethanol was proven to be effective in inhibiting the growth of tested bacteria. Tannin and phenolic compounds were antimicrobial agent that tend to be polar, thus both were extracted more in ethanol extract and resulting greater inhibition zone than acetone extract (Iloki-Assanga et al. 2015; Wijayanti, 2016; Medini et al. 2014; Chouksey et al.2013).

MIC and MBC value against the three tested bacteria respectively were: $1.59 \%$ and $6.36 \%(S$. aureus), $1.04 \%$ and $4.18 \%$ (E. coli), and $0.59 \%$ and $2.39 \%$ (B. cereus). The more susceptible the bacteria to anethole (Mohammed 2009). Different structure and outer cell membrane component caused different MIC and $\mathrm{MBC}$ value in $S$. aureus (Gram positive) and E. coli (Gram negative), this was also affected by membrane sensitivity against specific antimicrobial compounds. Gram negative bacteria have more complex cell wall which contain thin peptidoglycan (10-50\%). Antimicrobial compounds destroy outer cell membrane through porins (hydrophilic pathway) then separate phospholipids and lipopolysaccharides. Gram positive bacteria don't have outer cell membrane, but it's composed with thicker peptidoglycan $(90 \%)$, thus generally harder to be penetrated by antimicrobial compounds.

Star anise extract was unstable toward heating treatment and changes in $\mathrm{pH}$ value; but heating treatment at $60^{\circ} \mathrm{C}$ for 15 minutes and $\mathrm{pH} 4-5$ was able to exert closest result in inhibiting bacterial growth when compared to control extract. Generally as the heating temperature and time escalated, the antibacterial compounds lost its stability (thermolabile) because chemical structure of the compounds was degraded during heating and the antimicrobial activity decreased (Turek and Stintzing 2013; Sant'Anna et al. 2012; and Zhang et al. 2014). Ardiansyah (2002) reported that in certain specific condition, antibacterial activity could also increase as the temperature increases. Degradation of extract compounds formed new compounds which also have the potential to inhibit microorganism growth. Oxidized anethole compound would form 4-methoxy benzaldehyde (4-anisaldehyde) and anisketone which act as antimicrobial compound (Okamoto et al. 2002; Fahlbusch et al. 2003; Kosalec et al. 2005).

Escalation in $\mathrm{pH}$ also affected extract stability. The presence of fatty acids, such as hexadecanoic acid, 6octadecenoic acid, and stearic acid in extract made the extract more stable at $\mathrm{pH}$ 4-5. $\mathrm{pH}$ can affect the absorption of fatty acids in bacteria. As the $\mathrm{pH}$ increase, effectiveness of fatty acid absorption would decrease, thus the antibacterial activity also decreased (McGaw et al. 2002). Purbowati et al. (2016) and Pan et al. (2014) added that phenolic compounds in the extract are damaged by increased $\mathrm{pH}$ and causing the antibacterial activity became less effective. In reverse, a decrease in $\mathrm{pH}$ (an increase in $\mathrm{H}^{+}$ions) causes bacterial cytoplasm became less stable and it needs more energy to restore the cell's internal $\mathrm{pH}$ to normal state. Cell metabolism will be disturbed as more energy required to keep the normal state of cell's internal $\mathrm{pH}$, then the bacteria cells will die over time (Naufalin et al. 2006). The decrease in $\mathrm{pH}$ also increases the stability and effectiveness of phenolic compounds which are more hydrophobic in acidic conditions thereby facilitating the dissolution of 
bacterial membrane fat (Purbowati et al. 2016; Pan et al. 2014).

Toxicity value $\left(\mathrm{LC}_{50}\right)$ indicates the safety level of extract to be applied in food products. This test was done as the first step in other complex toxicity test. Based on the principle of Brine Shrimp Lethality Test (BSLT), the more amount of compound needed to kill $50 \%$ of shrimp larvae, then the compound will be categorized as more non-toxic. Juniarti et al. (2009) divides the toxicity level of $\mathrm{LC}_{50}$ into three categories which are: $\mathrm{LC}_{50}>1000 \mathrm{ppm}$ as non-toxic, $30<\mathrm{LC}_{50}<1000 \mathrm{ppm}$ as low toxic, and $\mathrm{LC}_{50}<1000 \mathrm{ppm}$ as toxic. Test result showed that star anise extract had $\mathrm{LC}_{50}$ of $212.09 \mathrm{ppm}$ (low toxic). Nakamura (1996) reported that veranisatin A, B, and C were toxic compound which contributed in star anise toxicity test, but the concentration of veranisatin A, B, and $\mathrm{C}$ in dry star anise were low, respectively, $0.00016 \%, 0.00010 \%$, and $0.000015 \%$ and it's categorized as safe to use in medicine and food products. FDA already classified Illicium verum Hook. f. as generally recognized as safe (IOFI 2017). Dewi et al. (2012), Soetan and Oyewole (2009), and Yunilla (2016) added that the natural antinutrient bioactive components formed by plant metabolism can also be toxic, such as glycosides, tannins, lignin, triterpenoids, oxalates, and amino acids. Low toxicity is considered safe and harmless if consumed as herbal intake at the right dose (Yunilla 2016). Further in vivo research is needed as dose reference for the application in food products that are safe for humans (BPOM 2014).

The major antibacterial compound in star anise extract, including terpenoids (anethole, $\beta$ caryophyllene, $\beta$-bisabolene, 2,6-dimethyl-6-(4methyl-3-pentenyl)-2-norpinene, $\beta$-Linalool, $p$ allylanisole, Trans- $\gamma$-bisabolene); and minor antibacterial compound, including fatty acids (6octadecenoic acid, hexadecanoic acid, stearic acid) and benzaldehyde (methoxy acetophenone, 4-anisaldehyde, 3-propenylphenol). All component were categorized as essential oil that could act as antibacterial agent (Attokaran, 2017; Aly et al. 2016; Taniguchi et al. 2014; Herman et al. 2016; Andrade et al. 2015; Okatomo et al. 2002; Fahlbusch et al. 2003; Chong et al. 2015; Carneiro et al. 2017; Dahham et al. 2015; McWilliams, 2006; Courtois et al. 2012; Rai et al. 2011; Marteau et al. 2016; Karimi et al. 2015; Uitterhaegen et al. 2016). Okamoto et al. (2002), Tisserand and Young (2014), and Kosalec et al. (2005) added that oxidized anethole will form anisketone which also acts as antimicrobial agent. In the recent study of Alhajj et al. (2019) showed that star anise alcoholic extract have antibacterial and antifungal activities and could be used as natural antimicrobial agent. The stability of star anise volatile essential oil and its antibacterial activity can be significantly enhanced by using HPCD encapsulation (Zhang et al. 2018).

\section{REFERENCES}

Aguda R, Chen CC. 2016. Solubility of nutraceutical compounds in generally recognized as safe solvents at 298K. Int J Chem Eng Appl. 7(5):289-294. doi: 10.18178/ijcea.2016.7.5.591.

Ahmad AF, Youssef SH. 2015. Chemical composition and bioactive properties of Illicium verum (star-anise) extracts prepared by different methods. JCBPSC. 5(2):1160-1170.

Alhajj MS, Qasem MAA, Nabi ARJE, Al-Murarrej SI. 2019. In-vitro antibacterial and antifungal effects of high levels of chinese star anise. Braz J Poult Sci. 21(1):1-8. doi: 10.1590/1806-9061-2016-0427.

Andrade TCB, De Lima SG, Freitas RM, Rocha MS, Islam T, Da Silva TG, Militao GCG. 2015. Isolation, characterization and evaluation of antimicrobial and cytotoxic activity of estragole, obtained from the essential oil of Croton zehntneri (Euphorbiaceae). An Acad Bras Cienc. 87(1):173-182. doi: 10.1590/00013765201520140111.

Aly SE, Sabry BA, Shaheen MS, Hathout AS. 2016. Assessment of antimycotoxigenic and antioxidant activity of star anise (Illicium verum) in vitro. J Saudi Soc Agric Sci. 15:20-27. doi: 10.1016/j.jssas.2014.05.003.

AOAC. 2005. Official methods of analysis of the association of official analytical chemists. Washington: AOAC Inc.

Ardiansyah. 2002. Kajian aktivitas antimikroba ekstrak daun beluntas (Plucea indica L.). Bogor: Institut Pertanian Bogor.

Attokaran M. 2017. Natural food flavors and colorants $2^{\text {nd }}$ ed. Chicago: John Wiley \& Sons.

Badal S, Delgoda R. 2017. Pharmacognosy: fundamentals, applications and strategy. Cambridge: Elsevier Inc.

Baldosano HY, Castillo BMG, Elloran CDH, Bacani FT. 2015. Effect of particle size, solvent and extraction time on tanning extraction from Spondias purpurea bark through soxhlet extraction. Manila: Presented at the DLSU Research Congress, March 2-4.

Bloomfield SF. 1991. Assessing antimicrobial activity. Oxford: Blackwell Scientific Publication.

Carneiro NS, Alves CCF, Egea MB, Martins CHG, Silva TS, Bretanha LC, Belleste MP, Micke GA, Silberira EV, Miranda MLD. 2017. Chemical composition, antioxidant, and antibacterial activities of essential oils from leaves and flowers of Eugenia klotzschiana Berg 
(Myrtaceae). An Acad Bras Cienc. 89(3):1907-1915. doi: 10.1590/0001-3765201720160652.

Chong SP, Osman MF, Bahari N, Nuri EA, Zakaria R, AbdulRahim K. 2015. Agarwood inducement technology: a method for producing oil grade agarwood in cultivated Aquilaria malaccensis Lamk. J Agrobiotech. 6:1-16.

Chouksey D, Upmanyu N, Pawar R. 2013. Central Nervous System Activity of Illicium verum Fruit Extracts. Asian Pac J Trop Med. 6(11):869-875. doi: 10.1016/S19957645(13)60155-8.

Courtois EA, Baraloto C, Paine CET, Petronelli P, Blandinieres PA, Stien D, Houel E, Bessiere J, Chave J. 2012. Differences in volatile terpenes composition between the bark and leaves of tropical tree species. Phy to che mis try. $82: 81-88$. d o i : 10.1016/j.phytochem.2012.07.003.

Dahham SS, Tabana YM, Iqbal MA, Ahamed MBK, Ezzat MO, Majid ASA, Majid AMSA. 2015. The anticancer, antioxidant, and antimicrobial properties of the sesquiterpene $\beta$-caryophyllene from the essential oil of Aquilaria crassna. Molecules. 20(7):11808-11829. doi: 10.3390/molecules200711808.

Das MP and Kumar SS. 2013. Preliminary phytochemical analysis of Illicium verum and Wedelia chinensis. Int J PharmTech Res. 5(2):324-329.

Dasgupta A, Klein K. 2014. Antioxidants in food, vitamins and supplements: prevention and treatment of disease. San Diego: Elsevier.

Dewi CSU, Soedharma D, Kawaroe M. 2012. Komponen fitokimia dan toksisitas senyawa bioaktif dari lamun Enhalus acoroides dan Thalassia hemprichii dari pulau Pramuka, DKI Jakarta. Jurnal Teknologi Perikanan dan Kelautan. 3(2):23-27.

Fahlbusch KG, Franz-Josef H, Panten J, Pickenhagen W, Schatkowski D, Kurt B, Garbe D, Surburg H. 2003. Flavors and fragrances in Ullmann's encyclopedia of industrial chemistry. Weinheim: Wiley-VCH.

Handayani H, Sriherfyna FH. 2016. Ekstraksi antioksidan daun sirsak metode ultrasonik bath (kajian rasio bahan: pelarut dan lama ekstraksi). Jurnal Pangan dan Agroindustri. 4(1):262-272.

Herman A, Tambor K, Herman A. 2016. Linalool affects the antimicrobial efficacy of essential oils. Curr Microbiol. 72(2):65-72. doi: 10.1007/s00284-015-0933-4.

Iloki-Assanga S, Lewin-Lujan LM, Lara-Espinoza CL, GilSalido AA, Fernandez-Angulo D, Rubio-Pino JL, Haines DD. 2015. Solvent effects on phytochemical constituent profiles and antioxidant activities, using four different extraction formulations for analysis of Bucida buceras L. and Phoradendron californicum. BMC Res Notes. 8:396-410. doi: 10.1186/s13104-015-1388-1.

International Organization of the Flavor Industry (IOFI). 2017. Global reference list of natural complex substances/natural flavouring complexes available from https://jr.chemwatch.net/galleria/LEGSREGS/40-1-11547-0-0-AA-20170217.pdf.

Juniarti, Osmeli D, Yuhernita. 2009. Kandungan senyawa kimia, uji toksisitas (brine shrimp lethality test) dan antioksidan (1,1-diphenyl-2-pikrilhydrazyl) dari ekstrak daun saga (Abus precatorius L.). Makara Sains. 13(1):50-54. doi: 10.7454/mss.v13i1.378.

Karimi E, Jaafar HZ, Ghasemzadeh A, Ebrahimi M. 2015. Fatty acid composition, antioxidant and antibacterial properties of the microwave aqueous extract of three varities of Labisia pumila Benth. Biol Res. 48(1):9-14. doi: 10.1186/0717-6287-48-9.

Khalaphallah R. 2015. Antimicrobial activity of some heterocyclic compounds and herbal extracts on plant pathogens. Chem Sci Rev Lett. 4(13):171-178.

Khasanah I. 2014. Ekstrak etanol daun kersen (Muntingia calabura L.) sebagai antibakteri terhadap Staphylococcus agalactiae penyebab mastitis subklinis pada sapi perah. Malang: Universitas Brawijaya.Kosalec I, Pepeljnjak S, Kustrak D. 2005. Antifungal activity of fluid extract and essential oil from anise fruits (Pimpinella anisum L., Apiaceae). Acta Pharm. 55:377385.

Marteau C, Guitard R, Penverne C, Favier D, Rataj VN, Aubry JM. 2016. Boosting effect of ortho-propenyl substiuent on the antioxidant activity of natural phenol. Food Chem. 196:418-427. doi: 10.1016/j.foodchem.2015.09.007.

McGaw LJ, Jager AK, Staden JV. 2002. Antibacterial effects of fatty acids and related compounds from plants. S Afr J Bot. 68:417-423. doi: 10.1016/S0254-6299(15)30367-7.

McWilliams M. 2006. Nutrition and dietetics $8^{\text {th }}$ ed. Jurong: Pearson Education Inc.

Medini F, Fellah H, Ksouri R, Abdelly C. 2014. Total phenolic, flavonoid and tannin contents and antioxidant and antimicrobial activities of organic extracts of shoots of the plant Limonium delicatulum. J Taibah Uni Sci. 8(3):216-224. doi: 10.1016/j.jtusci.2014.01.003.

Mohammed MJ. 2009. Isolation and identification of anethole from Pimpinella anisum L. Fruit oil: an antimicrobial study. J Pharm Res. 2(5):915-919.

Nakamura T, Okuyama E, Yamazaki M. 1996. Neurotropic components from star anise (Illicium verum Hook. f.). Chem Phar Bull. 44(10): 1908-1914. doi: 10.1248/cpb.44.1908.

am PN, Lien PTK, Hoa TT, Huong CM, and Thien D. 2017. Microwave assisted soxhlet extraction of essential oil from Vietnamese star anise fruits (Illicium verum Hook. f.) and their chemical composition. Emir J Food Agric. 29(2):131-137. doi: 10.9755/ejfa.2016-05-559.

Naufalin R, Jenie BSL, Kusnandar F, Sudarwanto M, Rukmini HS. 2006. Effects of $\mathrm{pH}, \mathrm{NaCl}$ and teating on the antibacterial stability of kecombrang. Jurnal TIP. 
17(3):61-74.

Okamoto K, Narayama S, Katsuo A, Shigematsu I, Yanase H. 2002. Biosynthesis of p-anisaldehyde by the white-rot basidiomycete Pleurotus ostreatus. J Biosci Bioeng. 93(2):207-210. doi: 10.1263/jbb.93.207.

Pan X, Mak LM, Nakako H. 2014. Efficacy of essential oils on inactivation of Escherichia coli $\mathrm{O} 157: \mathrm{H} 7$ in vegetable juice. Food Sci Technol Res. 20(5):1043-1049. doi: 10.3136/fstr.20.1043.

Peter KV. 2001. Handbook of herbs and spices. Boca Raton: CRC Press.

Purbowati ISM, Syamsu K, Warsiki E, Sri H. 2016. Stabilitas senyawa fenolik dalam ekstrak dan nanokapsul kelopak bunga rosella pada berbagai variasi $\mathrm{pH}$, suhu dan waktu. Agrointek. 10(1):31-40. doi: 10.21107/ agrointek.v10i1.2023.

Rai M, Acharya D, Rios JL. 2011. Ethnomedicinal Plants: Revitalization of traditional knowledge of herbs. Boca Raton: CRC Press.

Sangi M, Momuat L, Kumaunang M. 2012. Uji toksisitas dan skrining fitokimia tepung gabah pelepah aren (Arenga pinnata). Jurnal Ilmiah Sains. 12:128-134. doi: 10.35799/jis.12.2.2012.716

Sant'Anna V, Cladera-Olivera F, Brandelli A. 2012. Kinetic and thermodynamic study of thermal inactivation of the antimicrobial peptide P34 in milk. Food Chem. 130:8489. doi: 10.1016/j.foodchem.2011.07.001.

Sivakumar P, R NS, B JP, M JT, N, P, S, K H. 2016. Antimicrobial activity of selected spices - a bio preservative approach. J Chem Pharm Sci. 9:304-307.

Shete HG, Chitanand MP. 2014. antimicrobial activity of some commonly used Indian spices. Int J Curr Microbiol App Sci. 3:765-770.

Soetan KO, Oyewole OE. 2009. The need adequate processing to reduce the antinutritional factors in plants used as human foods and animal feeds. Afr J Food Sci. $3: 223-232$.

Surono IS, Subdibyo A,Waspodo P. 2016. Pengantar keamanan pangan untuk industri pangan. Yogyakarta:
Deepublish.

Taniguchi S, Shinonaga YH, Tamaoki D, Yamada S, Akimitsu K, Gomi K. 2014. Jasmonate Induction of the monoterpene linalool confers resistance to rice bacterial blight and its biosynthesis is regulated by JAZ protein in rice. Plant Cell Environ. 37:451-461. doi: 10.1111/pce.12169.

Tisserand R, Young R. 2014. Essential oil safety: a guide for health care professionals $2^{\text {nd }}$ ed. China: Elsevier.

Turek C, Stintzing FC. 2013. Stability of essential oils: a review. Compr Rev Food Sci Food Saf. 12:40-53. doi: 10.1111/1541-4337.12006.

Uitterhaegen E, Sampaio KA, Delbeke ELP, Greyt WD, Cerny M, Evon P, Merah O, Talou T, Stevens CV. 2016. Characterization of French coriander oil as source of petroselinic acid. Molecules. 21:02-1215. doi: 10.3390/molecules21091202.

Wei L, Hua R. Li M, Huang Y, Li S, He Y, Shen Z. 2014. Chemical composition and biological activity of star anise Illicium verum Extracts against maize weevil, Sitophilus zeamais adults. J Insect Sci. 14:1-13. doi: 10.1093/jis/14.1.80.

Wijayanti MN. 2016. Uji Aktivitas antioksidan dan penerapan kadar fenolik total ekstrak etanol buah buni (Antidesma bunius (L.) Spreng) dengan metode 2,2-diphenyl-1picrylhydrazyl (DPPH) dan metode folin-ciocalteu. Yogyakarta: Universitas Sanata Dharma.

Yunilla I. 2016. Kajian aktivitas dan stabilitas antibakteri ekstrak daun bintaro (Cerbera oddolam Gaertn.). Tangerang: Universitas Pelita Harapan.

Zhang G, Yuan C, Sun Y. 2018. Effect of selective encapsulation of hydroxypropyl- $\beta$-cyclodextrin on components and antibacterial properties of star anise essential oil. Molecules. 23(5): 1126. doi: 10.3390/molecules23051126.

Zhang J, Han J, Oyeleye A, Liu M, Liu X, Zhang L. 2014. Extraction methods of natural products from traditional Chinese medicines. Methods Mol Biol. 1263:177-185. doi: 10.1007/978-1-4939-2269-7_14. 